\title{
THE INTENDANT SYSTEM IN SPANISH AMERICA
}

\author{
BY \\ LILLIAN ESTELLE FISHER, Ph.D. \\ Associate Professor of History in \\ Oklahoma College for Women
}

UNIVERSITY OF CALIFORNIA PRESS

BERKELEY, CALIFORNIA

1929 


\section{University of California Press}

Berkeley, CaLifornia

Cambridge University Press

LONDON, ENGLAND

PRINTED IN THE UNITED STATES OF AMERICA

August, 1929 
TO MY SISTER

HELEN GERTRUDE FISHER 

THE INTENDANT SYSTEM IN SPANISH AMERICA 
